\title{
Perkembangan Motif Sineas Film Indie Dalam Menghadapi Industri Film Mainstream
}

\author{
Yoppy Ardiyono \\ (yoppyardiyono123@gmail.com) \\ (Alumni Ilmu Komunikasi FTIK USM)
}

\begin{abstract}
The research aims to review to review determine the effect and its impact raised by motive - a motive the ada in the hearts period travel time history of film short against cinematographer-filmmaker as principal especially filmmakers left path (indie). The used platform theory research hearts singer adopts from theory commodification media vincent mosco. Singer helped shift theory understanding the motive filmmakers working hearts differences fundamental basis of political pressure economic happens under with demands regime. The method used is descriptive qualitative research methods. Data collection techniques through observation of the environment of an independent film live and in-depth interviews with speakers including $m r$. Yang prayer orangutan direct contact 'with realm of research. Coupled with study to review the literature references adding insight research. And that was concluded change appears motif among indie film cinematographer it is true the situation is closely linked to the mainstream industry, konstilasi politics, and the orientation of capitalism. Necessary their one thing is clear and systematic regulation from the government to the future movement of currents sidestream (indie) more with good operates professionally arranged, the air so that the contribution of indie cinema film land for progress can feels good to yourself indie filmmakers as well as those of its main industries.
\end{abstract}

Kata Kunci: Film, Industri, Indie, Film Pendek

\section{Pendahuluan}

Dalam sejarah perkembangan perfilman mainstream di Indonesia, film - film indonesia mengalami banyak kemajuan yang sangat pesat. Saat ini perfilman tanah air sudah mampu menunjukkan keberhasilannya untuk menampilkan film yang lebih dekat dengan budaya bangsa Indonesia. Hal tersebut di buktikan dengan munculnya film-film berkualitas paska tidurnya kreatifitas industri film Indonesia di tahun 1990an akibat adanya krisis identitas bangsa dalam pengangkatan tema - tema film yang di produksi pada kurun waktu tersebut. Banyak faktor yang mendasari kenapa ketika itu industri-industri di Indonesia memilih untuk lebih banyak memproduksi filmfilm dengan genre "khusus" dan bisa dikatakan tidak mencerminkan budaya bangsa Indonesia sesungguhnya. Mulai dari runtuhnya idealisme sineasnya dalam berkarya, sampai faktor ekonomi yang mengharuskan para sineas tersebut mau tidak mau di tuntut untuk mengikuti pasar jika tetap ingin berada dalam lingkaran industri perfilman yang diakui (mainstream). Sekedar menilik kebelakang, sejarah produksi perfilman Indonesia mengalami beberapa periode pasang surut dalam perkembangan dinamika keindustrian. Pada tahun 1987 misalnya, produksi judul film Indonesia mencapai 124 judul produksi, jumlah ini 
menurun menjadi 106 judul film pada 1989. Pada tahun 1990 terdapat kenaikan produksi sebanyak 115 judul, namun tahun 1999 hanya diproduksi 4 judul film (Pandjaitan dan Aryanti, 2001). Terjadi krisis kepercayaan multi dimensional industri film terhadap para sineas ketika itu mengakibatkan menurunnya produksi film yang tidak hanya terjadi dalam segi kuantitas saja, akan tetapi juga secara kualitas film. Hal tersebut memicu para pembuat film untuk akhirnya satu persatu mulai menanggalkan idealismenya dalam membuat film dan menuruti permintaan pasar atau pemilik modal. Tentu yang melatar belakangi tidak lain adalah persoalan ekonomi. Pilihan tersebut diambil untuk dapat bertahan hidup di dalam industri film itu sendiri karena sebagian besar para sineas film hidup dan bergantung di dalamnya. Meskipun demikian, tidak sedikit pula yang pada akhirnya memilih untuk berhenti dan tidak menggadaikan idealismenya demi memenuhi tuntutan pasar. Walau konsekuensi yang harus diterima adalah kehilangan banyak kesempatan untuk memproduksi film dan tidak dilirik oleh komponen produksi/pemilik modal.

Idealnya sebuah industri seharusnya memberikan ruang yang seluas mungkin kepada sineas, baik itu sineas industri pada umumnya (mainstream) atau para sineas jalur kiri/indie (sidestream) yang sering kali terabaikan oleh industri besar perfilm tanah air. Padahal sineas lokal dan daerah memiliki potensi yang sangat besar untuk ikut mengembangkan perfilman di negeri ini. Mengingat begitu banyak potensi yang bisa dikembangkan dalam industri perfilman di Indonesia, sudah seharusnya industri juga mendukung pergerakan sineassineas jalur kiri yang serius menggarap film sebagai konten kearifan lokal namun minim publikasi tersebut. Sehingga kerja sama yang nantinya diciptakan dapat menguntungkan kedua belah pihak, baik untuk kehidupan produksi film itu sendiri maupun untuk nasib para sineas jalur kiri yang bisa menjadi jalan membuka peluang untuk lebih ekspresif dalam mengembangkan tema-tema film yang ada saat ini. Karena film-film jalur kiri terkenal akan kekayaan temanya dan lebih berani dalam mengembangkan ide-ide kreatif, tentu saja hal tersebut akan sangat berkontribusi sekali dalam pembentukan karakter film Indonesia yang sudah lama mengalami kejenuhan dalam penyugguhan tema-temanya kepada penonton.diberikan ruang untuk melawan ketidakadilan tersebut. Karena sebab yang demikian, maka makin berat perjuangan sineas film jalur kiri/indie (sidestream) untuk bersaing atau sekedar mempertahankan diri agar selalu berhaluan dalam berkarya dan tetap pada prinsipnya. Kesulitan yang mendera dan bertubi - tubi mulai dari masalah perijinan, proses produksi, pendanaan sampai pengapresiasian yang minim membuat sineas film jalur kiri/indie (sidestream) pada akhirnya berpindah haluan dan mengikuti selera pasar, meskipun sering kali itu tidak sesuai dengan apa yang menjadi idealismenya sendiri. Demi untuk mempertahankan eksistensi dan pangan, maka inilah jalan yang diambil. Sehingga tidak heran ketika terjadi banyak penurunan kualitas perfilman tanah air bermula dari keputus asaan para sineasnya dalam mempertahankan idealisme yang sudah susah payah di tumbuhkan selama berada di industri jalur kiri (sidestream) karena tidak ada kesempatan untuk berkembang apalagi menciptakan industri sendiri.

Dan sudah barang tentu pemerintah haruslah memberikan perhatian lebih kepada industri jalur kiri (sidestrean) 
untuk tumbuh. Karena dari sinilah bakat - bakat serta bibit - bibit kreatif tumbuh dan berkembang dengan sangat baik dan dinamis, yang nantinya akan beregenerasi baik secara individu maupun ide kreatifnya. Sehingga industri perfilman di Indonesia akan jauh lebih baik di masa depan dan tidak terpuruk seperti sekarang yang hampir tidak memiliki nilai pendidikan apalagi pesan moral dalam tiap tontonannya.

\section{Tinjauan Pustaka}

\section{Teori Politikal Ekonomi Media Komodifikasi Mosco}

Dalam penjelasannya, Berawal dengan menjelaskan ekonomi politik klasik dari Adam Smith, David Ricardo dan lain-lain. Mosco menawarkan beberapa definisi ekonomi politik, yang boleh dibilang yang paling berguna adalah "studi tentang hubungan sosial, khususnya hubungan kekuasaan, yang saling berkaitan dari proses produksi, distribusi sampai konsumsi sumber daya media". Hal tersebut merupakan konsep awal menelaah ekonomi politik seperti juga yang di gagas oleh Gamham: "In order to understand the structure of our culture, it's production. Consumption and reproduction and of the role of the mass media in that process, we need to confront some of the central questions of political economy in general (Graham, 1979: 120).

Hal ini apabila di asumsikan dengan kondisi ideologi sineas perfilman sekarang, utamanya jalur industrinya, maka akan ditemukkan satu titik temu penting bahwa tingkat pergeseran orientasi sineas dalam berkarya sangat dipengaruhi oleh motif ekonomi yang ada serta faktor tekanan politik industri yang memaksa para sineas ini untuk mau tidak mau bekerja sebatas memenuhi tuntutan pasar semata tanpa memperdulikan idealisme dalam berkarya. Faktor pendorong utamanya tentu karena anggapan bahwa film (karya) sudah terjebak sebagai sebuah komoditas yang memiliki nilai tukar (komodifikasi) tertentu sehingga mengabaikan prinsip nilai yang terkandung didalamnya. Secara singkat, komodifikasi merupakan upaya mengubah apapun menjadi komoditas atau barang dagangan sebagai alat mendapatkan keuntungan.

Komodifikasi berhubungan dengan bagaimana proses transformasi barang dan jasa beserta nilai gunanya menjadi suatu komoditas yang mempunyai nilai tukar pasar. Secara umum, produk media (film) umumnya bersifat informatif dan hiburan. Tiga hal yang terkait dalam hal ini adalah isi media, konsumen (penonton)/khalayak, dan iklan. Isi dalam media adalah komoditas yang dapat menaikkan jumlah konsumen (penonton) atau khalayak dan jumlah tersebut dapat dijual pada pengiklan. Dan pendapatan yang masuk merupakan keuntungan dan dapat digunakan untuk ekspansi media (Mosco, 1996:141).

Dari ekspansi media besar-besaran itulah yang pada akhirnya memunculkan sebuah industri. Industri yang mencul tersebut membawa bentuk dan pola baru secara sistematis dan terstruktur sehingga membuat satu tatanan baru dalam dunia industri perfilman yang wajib di ikuti untuk melangsungkan roda kehidupan yang ada didalamnya. Tidak peduli apakah hal tersebut pada nantinya ada nilainilai atau batasan-batasan yang di langgar, selama menguntungkan dan keuntungan tersebut dapat dibagi dengan pemilik kekuasaan (pemerintahan) maka hal tersebut akan tetap berjalan. Sekali pun ada bentuk protes atau sanksi-sanksi yang di berikan kepada satu film tertentu karena 
mengabaikan nilai-nilai, hal tersebut hanyalah sebatas lips service semata.

Karena faktanya tetap terus bermunculan film - film dengan bentuk yang sama meskipun dengan kemasan yang berbeda. Semua itu bisa terjadi karena tentu ada profit oriented yang menjadi nilai tukarnya. Selama hal tersebut sama-sama menguntungkan, maka akan selalu ada toleransi bagi industri tersebut untuk dapat memproduksi film-film dengan label industri. Dengan begitu, ketika sebuah industri sudah terbentuk dan memiliki kekuatan penuh untuk mengatur jenis film tertentu sebagai komoditasnya, industri tersebut akan sangat memiliki kendali secara penuh untuk mengatur para sineas yang ingin berkarya dan mengubah serta idealisme yang ada pada diri sineas tersebut dengan power yang industri tersebut miliki tanpa memperdulikan lagi proses pembentukan idealisme seorang sineas yang telah lama berlangsung demi mengejar permintaan pasar.

Industri memanfaatkan media, dalam hal ini adalah film, untuk dijadikan komoditas barang dagangan mereka dan termasuk 'penjerumusan' idealisme sebagian sineas agar mengubah orientasi mereka untuk tidak lagi perlu memikirkan hal - hal yang bersifat ideal demi memuaskan pasar/konsumen yang dimana di posisikan sebagai poros 'pemasukan' yang sebenarnya juga tidak luput dari bidikan pembentukan konsumeritas gaya baru dengan mendidik mereka (konsumen) untuk tidak lagi dapat berfikir kritis dan hanya sekedar menjadi penikmat atas konten yang di sajikan tanpa protes. Sederhananya, industri film melalui medianya yaitu film, memanfaatkan sineas untuk memenuhi tuntutan mereka dengan menjanjikan keuntungan yang besar apabila mereka menurutinya dan menjadikan konsumen/penonton sebagai pasar utamanya untuk mengambil keuntungan yang sebesar besarnya bagi perluasan industri itu sendiri dengan cara mengangkat nama sineas dalam judul karya tertentu serta mempromosikan judul - judul yang 'menjual' dengan konten sesuai selera pasar yang sebelumnya telah dibentuk oleh industri itu sendiri, sehingga konsumen/penonton tertarik dengan judul - judul film yang di suguhkan dan itu merupakan kesempatan bagi industri untuk mengambil suatu keuntungan yang tujuannya tentu saja makin mengkokohkan posisi mereka untuk dapat mempengaruhi sineas-sineas baru agar mau berpaling dari industri idealisme nya menuju ke industri 'yang sesungguhnya' (Vincent Mosco, 1996: 157).

Yang perlu dicermati dalam komodifikasi adalah dampak besarnya terhadap pertumbuhan tiga segmen penting dalam industri perfilman; industri/prosuden, sineas film, dan penonton/konsumen. Dimana ketiganya merupakan sebuah rantai kehidupan yang menentukan berjalannya sebuah mekanisme dan cara pandang yang bisa mempengaruhi pola berfikir ketiganya dalam memandang sebuah industri.

\section{Teori Rekomodifikasi Clause Offe}

fenomena pergeseran sebuah alur industri perfilman, khususnya perfilman Indonesia dari masa ke masa dengan melakukan telaah lebih dalam terkait perbandingan antara dua industri yang berbeda dan pergeseran perilaku pelaku industri itu sendiri di dalamnya dari masing - masing industri yang telah di masukinya. Dampak utama atas komodifikasi yang diterapkan saat ini adalah hilangnya esensialisme di dalam 
film, baik dari segi produksi, sampai konsumsi film. Bahwa tindakan atas isi media bisa saja dilakukan, namun seharusnya idealisme pembuatan serta konsumsi isi film haruslah tetap menjadi otonomi tak terbatas yang dimiliki oleh sebuah produk film, sineas film itu sendiri sebagai pembuatnya dan penonton/konsumen sebagai pengakses sekaligus penikmat film - film tersebut. Istilah 'rekomodifikasi administratif' adalah di dalam budaya konsumsi seperti era postmodernisme, mekanisme pasar dianggap telah gagal untuk 'melawan' kuasa penonton/konsumen (Claus Offe, Contradictions of the welfare state, 1984). Inilah sikap yang seharusnya di ambil oleh sineas film jalur kiri/indie (sidestream) untuk dapat melawan arus kuat dari gerakan komodifikasi yang coba di terapkan oleh industri utama (mainstream) dalam usaha melakukan penggiringan orientasi industri jalur kiri agar beralih menjadi sebuah penyatuan pasar besar yang dikendalikan penuh oleh industri utama (mainstream) sebagai pemegang regulasi tertinggi. Hal ini tentu saja menjadi daya pikat bagi pelaku di dalam industri jalur kiri untuk melakukan 'toleransi' dan pengambilan jalan tengah yang bertujuan untuk mempertahankan posisi pasar industri jalur kiri itu sendiri agar tidak seluruhnya hilang idealisme karena termakan komodifikasi terapan yang dilakukan oleh industri utama (mainstream) secara masif. Sebetulnya fokus yang dilakukan oleh sineas atau penggiat film jalur kiri/indie (sidestream) adalah melakukan pendidikan terhadap penonton dalam rangka melakukan perlawanan terhadap komodifikasi industri utama (mainstream) yang dalam hal ini industri tersebut menempatkan penonton/konsumen sebagai poros pasar yang harus di turuti permintaannya demi sebuah keuntungan yang nantinya akan berimbas pada kemampuan mereka untuk melakukan ekspansi industri besar - besaran sehingga akan semakin mengkokohkan posisi mereka dalam memegang 'aturan main' khususnya dalam industri film yang ada saat ini. Hal tersebut sangat di fahami oleh penggiat film jalur kiri/indie (sidestream) sehingga menurutnya dengan cara melakukan 'pendidikan pasar' (penonton), industri jalur kiri (sidestream) berusaha melakukan perlawanan terhadap 'aturan main' yang ada dengan memahamkan penonton tentang esensialisme sebuah tontonan (dekomodifikasi). Dekomodifikasi ini kemudian disusun secara sistematis dengan melibatkan program - program kegiatan serta pemetaan regulasi yang ada dengan tujuan untuk mematahkan kepentingan produsen industri utama (mainstream) yang terlalu banyak keinginannya. Hal tersebut dapat difahami oleh industri jalur kiri (sidestream) untuk menerapkan 'strategi ranah privat' sebagai senjata ampuh untuk melakukan perlawanan dan perubahan terhadap gerakan kapitalisme yang terus dibentuk oleh industri utama (mainstream) sebagai orientasi satu satunya dalam berkarya. Salah satu bentuk perlawanan terhadap cara berfikir kapitalisme ala industri utama (mainstream) tersebut yaitu dengan 'mendidik pasar'. Sineas - sineas jalur kiri/indie (sidestream) dalam usahanya, terus bergerak membuat pasar sendiri melalui berbagai kegiatan baik yang bersifat edukatif sampai acara - acara penganugrahan karya sineas secara mandiri. Hal ini tentu sangat baik untuk menumbuhkan moral sineas di dalamnya maupun penikmat film - film jalur kiri/indie (sidestream) yang saat ini boleh dikatakan masih segmented. Kekonsistensian mereka dalam melakukan pergerakan tersebut dapat 
menumbuhkan lingkungan berkarya itu sendiri menjadi sebuah ruang lingkup berkarya yang besar tanpa harus kehilangan idealisme dalam tiap penyuguhan karyanya. Sehingga menjaga sineas yang ada didalamnya tetap dalam orientasi berfikir layaknya jalur kiri/indie (sidestream). Kapitalisme selalu membawa ketidak stabilan dalam identitas, termasuk narsisme identitas personal. Hal tersebut berkaitan erat dengan otonomi personal yang tidak dapat dipengaruhi oleh tindakan eksternal secara mudah (Stuart Hall, 1997: 166).

\section{Pembahasan \\ Motif Politik}

Pada penelitian fenomena perkembangan motif sineas dalam kurun waktu perjalanan berkarya dan perbedaan jenis industri film sebagai wadah klasifikasi karya atau media ini, penulis memulai pendekatan dari teori politikal ekonomi media milik Mosco (The Political Economy Communication, 1996) dalam mencari dan menganalisa seputar motif politik eknomi dalam lingkup para sineas tentang orientasi berkaya dan sifat industri (media) itu sendiri sebagai wadah apresiasi dari karya tersebut, serta yang paling memberi pengaruh terhadap perubahan motif ekonomi politik di tubuh insan perfilman secara khusus. Bahwa ekonomi politik komunikasi adalah sebuah pengkajian yang secara umum digunakan untuk memadukan kerangka teoritik komunikasi dengan kerangka teoritik politik dan ekonomi. Ketertarikan pada kajian ekonomi dan politik menjadikan dunia perfilman pendek sebagai ranah yang rentan terhadap pengaruh keduanya.

Jika kita melihat perjalanan film pendek negeri ini, maka akan kita dapati bagaimana kuatnya pengaruh kekuatan politik birokrat di Era Orde Baru. Motif yang peneliti dapati dari sejarah perjalanan pada era ini adalah bagaimana para sineas film berkarya di bawah tekanan demi eksistensi keryanya. Beberapa sineas dengan karakter berbeda mengambil jalannya masing-masing sebagai respon terhadap kondisi yang harus di hadapi kala itu, yakni ada yang merasa perlu untuk melakukan perlawanan seperti Gotot Prakoso dan kawan-kawan, dan ada yang memilih mengikuti regulasi yang berjalan serta mengabaikan pergerakan sidestream. Keduanya bukanlah hal yang salah untuk dipilih karena tidak ada opsi yang paling tepat jika sedang membicarakan idealisme berkarya. Ketika sudah membicarakan konstilasi politik suatu negara maka secara otomatis hal tersebut akan berkaitan dengan pemecahan masalah-masalah yang berkisar pada produksi, distribusi alokasi, mobilisasi konsumsi barang dan jasa serta untung rugi dari hasil sebuah proses produksi dalam suatu ranah yang disebut dengan industri arus besar (mainstream). Menurut Mosco,

"Komodifikasi berhubungan dengan bagaimana proses transformasi barang dan jasa beserta nilai gunanya menjadi suatu komoditas yang mempunyai nilai tukar di pasar. Memang terasa aneh, karena produk media umumnya adalah berupa informasi dan hiburan. Sementara kedua jenis produk tersebut tidak dapat diukur seperti halnya barang bergerak dalam ukuran-ukuran ekonomi konvensional. Aspek tangibilitynya akan relatif berbeda dengan barang dan jasa lain" (Moscow, 1996: 126).

Hal inilah yang pada akhirnya mempersulit pilihan yang ada bagi 
sineas film pendek untuk mengarahkan karyanya pada sasaran yang tepat guna mendapatkan effect society seperti yang diharapkan. Peneliti mendapati bahwa selain daripada media hiburan, film merupakan media penyebar pemikiran atau propaganda yang di gunakan untuk mengumpulkan kekuatan dengan tujuan melakukan perlawanan atas sebuah rezim dan juga komoditas jualan bagi rumah-rumah produksi yang memanfaatkan situasi sulit perfilman dengan maksud memperoleh keuntungan dari pendistribusian karya.

\section{Motif Ekonomi}

Walaupun perfilman sidestream tidak banyak memberikan keuntungan secara finansial karena harus berjibaku menghidupi karyanya sendiri dengan mandiri, akan tetapi ternyata tidak menghalangi semangat pertumbuhannya sekalipun ketika itu peraturan dan sikap pemerintah sangat tidak mendukung.

Kekonsistensian mereka dalam melakukan pergerakan tersebut dapat menumbuhkan lingkungan berkarya itu sendiri menjadi sebuah ruang lingkup berkarya yang besar tanpa harus kehilangan idealisme dalam tiap penyuguhan karyanya. Ditambah perlawanan mereka terhadap penokohan pimpinan rezim ketika itu membuat jalur sidestream memiliki tantangan tersendiri untuk dipertahankan. Sekalipun ketika itu industri mainstream memberikan banyak keuntungan baik dari segi karir maupun finansial, akan tetapi pilihan untuk menjadi apa adanya masih banyak diminati dan dipilih sebagai jalur alternatif berkarya. Sehingga, sedikit banyak hal tersebut menjaga sineas yang ada didalamnya tetap dalam orientasi berfikir layaknya jalur kiri/indie (sidestream) sekalipun memang tidak dinafikkan bahwa kebutuhan keberlansungan hidup atau motif ekonomi selalu membarengi. Pandangan kapitalisme telah banyak mengubah tatanan masyarakat, tidak terkecuali dalam dunia perfilman sidestream, namun hal tersebut dipandang kritis oleh Stuart Hall. Hall berpendapat,

"Kapitalisme selalu membawa ketidakstabilan dalam identitas, termasuk narsisme identitas personal. Hal tersebut berkaitan erat dengan otonomi personal yang tidak dapat dipengaruhi oleh tindakan eksternal secara mudah" (Stuart Hall, 1997: 166).

Sineas tidak lagi berkutat pada masalah tentang bagaimana mencari jalan 'bertutur' dalam berkarya, akan tetapi soal distribusi karya yang ternyata tidak membawa perubahan yang sebanding dengan kebebasan menentukan tema cerita. Para penggiat sidestream kali ini harus berhadapan dengan sistem kapitalisme besar yang seakan-akan mengotak-kotakan sineas film kedalam dua kutub berhadapan, yakni mainstream dengan sidestream. Mereka membandingkan keduanya berdasarkan peta pemasaran dan segmentasi penonton, serta daya 'jual' yang didapatkan dari keduanya. Kemudian munculah semacam jurang pemisah antara sudut pandang industri mainstream dengan film-film sidestream. Hal tersebut dilihat dari bagaimana sebuah karya mampu atau tidak menghasilkan banyak penonton untuk datang menonton dan membayar tiket sebagai bentuk pengapresiasian karya.

Banyak dari sineas sidestream (indie) pada akhirnya memandang bahwa jalur sidestream adalah batu loncatan untuk menuju arus besar (mainstream) yang menjadi tolak ukur kesuksesan dalam berkarir dan berkarya. Tidak sedikit juga yang 
akhirnya memutuskan untuk memilih menjadi mainstream karena tuntutan ekonomi dan faktor eksistensi. Karena jika ingin bicara tentang masa depan dan hidup di dunia film, maka industri mainstream adalah jawaban atas hal tersebut. Sebagaimana pandangan Moscow,

"Memanfaatkan sineas untuk memenuhi tuntutan mereka dengan menjanjikan keuntungan yang besar apabila mereka menurutinya dan menjadikan konsumen/penonton sebagai pasar utamanya untuk mengambil keuntungan yang sebesar - besarnya bagi perluasan industri itu sendiri dengan cara mengangkat nama sineas dalam judul karya tertentu serta mempromosikan judul - judul yang 'menjual' dengan konten sesuai selera pasar yang sebelumnya telah dibentuk oleh industri itu sendiri, sehingga konsumen/penonton tertarik dengan judul - judul film yang di suguhkan dan itu merupakan kesempatan bagi industri untuk mengambil suatu keuntungan yang tujuannya tentu saja makin mengkokohkan posisi mereka untuk dapat mempengaruhi sineas-sineas baru agar mau berpaling dari industri idealisme nya menuju ke industri 'yang sesungguhnya", (Vincent Mosco, 1996: 157).

\section{Motif Karya Seni}

Meskipun dalam temuan penelitian dilapangan terdapat sebagian atau tidak sedikit juga sineas yang tidak begitu mempermasalahkan hal tersebut. Bagi sineas yang berpola pandang seperti ini, mereka memilih untuk tidak terlalu berpusing diri apakah itu mainstream atau sidestream, bagi mereka film adalah sebuah karya seni dan sudah sepatutnya sebuah karya seni yang menggugah dan kreatif layak mendapat apresiasi apapun bentuknya. Hanya memang permasalahan distrubis serta regulasi yang mengaturnya sudah sepatutnya juga menjadi bahan pertimbangan pemerintah supaya terkesan ada perhatian lebih bagi industri kreatif - terlepas itu mainstream atau sidestream - agar nantinya kedua arus tersebut bisa di tangani secara profesional sebagaimana yang telah dilakukan di negara-negara yang memiliki sistem pengelolaan film yang sudah maju. Sehingga dengan begitu tujuan tercapainya keselarasan dan keharmonisan antara dua kutub yang berbeda pandangan tersebut tidak saling bersinggungan dan dapat berjalan beriringan membangun perfilman tanah air yang semakin hari semakin menampakkan kedewasaannya dalam berkarya. Menurut Kristanto,

"Sejak awal perfilman nasional dibangun, bapak film Indonesia, Usmar Ismail berjuang agar film dimasukkan dan dipandang sebagai sebuah karya seni. Film memang sebuah karya seni, namun sebagai bentuk kesenian, film mencakup dua media utam yaitu pandang dan dengar yang kompleks memadukan berbagai bentuk kesenian yang disublimasikan menjadi satu bentuk produk kesenian dimana musik, lukis, teater, grafis, taxi, animasi, fotografi, puisi, dan masih banyak lagi bentuk kesenian lain yang dapat dikandungnya" (Kristanto dalam widagdo, 2011: 82).

\section{Kesimpulan}

Pada penelitian ini, peneliti menemukan dalam mempelajari perkembangan motif yang terjadi di kalangan sineas sidestream terhadap industri mainstream sampai saat ini, tidak bisa dipisahkan dari rentetan 
sejarah panjang semenjak awal mula terbentuknya jalur sidestream sampai mengalami perjalanan berliku yang tidak banyak dibicarakan dalam sejarah perkembangannya. Jangan sampai karena tidak mengetahui akar perjalanan perfilman sidestream membuat sineassineas yang ada didalamnya menjadi kehilangan daya juang dalam berkarya kemudian ditangkap dengan rasa yang sama dan cenderung setengah hati juga oleh pihak-pihak diluar sineas sidestream (baik investor, founding, penonton, atau festival film), sehingga film-film sidestream kehilangan 'ruh' untuk mempengaruhi pihak-pihak diluar tadi dalam memberikan antusiasme dan malah hanya berhenti pada lingkaran penggiatnya saja. Tentu kondisi semacam ini sangat disayangkan, jika melihat geliat pergerakan film-film sidestream sekarang jauh lebih masiv dengan jumlah produksi film yang tentunya jauh lebih banyak dari masamasa sebelumnya. Juga yang menarik adalah secara 'diam-diam' film-film sidestream (indie) tersebut sudah banyak yang sampai menembus festival-festival internasional. Motif sineas perfilman sidestream sejatinya tumbuh beragam tergantung dari kondisi latar belakang sosial dimana ia tumbuh. Penggiat film sidestream di era liberalisasi modern yang memandang sebuah motif sebagai salah satu bagian yang tak terpisahkan dari sineas baik apapun bentuk motif tersebut. Hal tersebut adalah simbol ekspresi diri yang coba ditunjukkan oleh masingmasing sineas. Menurutnya antara mainstream dan sidestream harusnya dapat saling mengisi dan memberi kesempatan agar terjalin keharmonisan, sehingga sineas tidak terus menerus terjebak dalam kondisi pengotakkotakan diri akibat hal yang di timbulkan oleh hegemoni kapitalisasi industri. Dan sudah sepatutnya hal tersebut tidak mengganggu kualitas berkarya meskipun tidak harus berada dalam jalur arus besar (mainstream). Keduanya dapat saling membangun dan mendukung dengan sudut pandang masing-masing sehingga tidak menjadikannya sebuah masalah besar untuk dikhawatirkan. Dan juga penyandaran atau ketergantungan terhadap regulasi dari pemerintah selaku pengelola kebijakan sebaiknya jangan terlalu diharapkan. Karena harusnya berkarya dan mengembangkan kualitas dengan atau tanpa regulasi harusnya tetap berjalan. Dengan optimis mampu akan dapat membangun sistem sendiri sebagaimana yang telah terjadi di negara-negara dengan arus film sidestream yang sudah maju.

\section{Daftar Pustaka}

Budi Indra Irwanto. 1999. Film, Ideologi dan Militer: Hegemoni Militer Dalam Sinema Indonesia . Yogyakarta: Media Pressindo.

Burhan Bungins H.M. 2007. Penelitian Kualitatif : Komunikasi, Ekonomi, Kebijakan Publik, dan Ilmu sosial, Jakarta : Kencana Prenama Media Group.

Filosa Gita Sukmono. 2013. Ekonomi Politik Media. Yogyakarta: Lingkar Media.

Gotot Prakosa. 1997. Film Pinggiran. Jakarta: FFTV-IKJ \& YLP. 2001. Ketika Film Pendek Bersosialisasi. Jakarta: Yayasan Layar Putih

Giddens, Anthony. 1971. Capitalism and Modern Social Theory. Cambridge: Polity Press. 
Hall, Stuart (Ed). 1997. Representation: Cultural Representations and Signifying Practices. London: SAGE Publication Ltd.

JB. Kristanto. 2004. Nonton Film, Nonton Indonesia. Jakarta: Kompas Media Nusantara.

Johan HM. Tjasmadi. 2008. 100 Tahun Bioskop Di Indonesia (1900 2000). Bandung: Megindo Tunggal Sejahtera.

M. Bayu Widagdo. 2011. Peran Pemerintah Dalam Pembuatan Kebijakan Perfilman Indonesia Pada Masa Orde baru Dan Reformasi. Semarang: Universitas Diponegoro.

McQuail, Danis. 2005. McQuail's Mass Communication Theory. London: SAGE Publication Ltd.

Mosco, Vincent. 1998. The Political Economy of Communication: Rethinking and Renewal. London: SAGE Publication Ltd.

Offe, Claus. 1984. Contradictions of the welfare state. Germany: The MIT Press. 